\title{
On the Emotive Phraseologisms with Kinesthetic Basis Taking Place in the Phraseological System of the English Language
}

\author{
Jamila Ramiz Abdullayeva ${ }^{1}$ \\ ${ }^{1}$ Department of Foreign Languages, Azerbaijan University of Languages, Baku, Azerbaijan \\ Correspondence: Jamila Ramiz Abdullayeva, Department of Foreign Languages, Azerbaijan University of \\ Languages, Baku, Azerbaijan. E-mail: jamila.abdullayeva.1@gmail.com
}

Received: January 20, 2016

Accepted: February 22, 2016 Online Published: March 28, 2016

doi:10.5539/ijel.v6n2p150

URL: http://dx.doi.org/10.5539/ijel.v6n2p150

\begin{abstract}
In the article emotive phraseologisms with kinesthetic basis, taking place in the phraseological system of the English language are analyzed. As the object of investigation, a group of chosen phraseological units expressing emotions and feelings of human being have been subjected to investigation. Study of this phraseosemantical field is one of the most discussed and complicated types of phraseological expressions, being linked with human emotions, and feelings which are unavailable for the direct observations. From this point of view, issues of means of conceptual-emotional state of human being acquire great importance. In our article we keep to the wide understanding of phraseology, object of which is all the stable set expressions with the complication of meaning possessing the signs of unchangeability.
\end{abstract}

Keywords: the English language, emotive phraseological units, kinesthetic, somatic components

\section{Introduction}

Nowadays formation of anthropocentric paradigms, brought to a new turn in linguistic researches directed to human being. Many of the local and foreign scholars devoted their scientific researches to this direction. More interest is given not only to the processes taking place within the language, but also to the interrelation with the language and thinking, language and culture, language and society, language and psychology. Study of conceptual categories is applied at the juncture of different branches: cognitive linguistics, ethnolinguistics, linguoculturology, and psycholinguistics, and has been devoted to the study of English phraseology.

Group of phraseological units expressing human feelings and emotions have not been chosen accidentally. Because firstly, phraseological units themselves characterize the appearance of internal emotional life of people and reflect them via self peculiar "mirror of human feelings, understandings and evaluations", and secondly, help us to understand in what manner they are activized, how they are revealed, what functions each of them carries out in the process of communication, especially in the speech of people.

Emotions in themselves show subjective attitude of people, which are expressed in mimic, pantomimic, intonation and at last by means of language. Language fixation of symptomatic reactions and physical state, associated with this or that emotion is the basis, on the ground of which in the naive map of the world imagination on the essential characteristics of this emotion is formed.

The author on the example of the emotive phraseological units such as look down (turn up) nose at somebody, with one's nose in the air, cast (make) sheep's eye at somebody, etc., considers and values the role of kinesthetic in the formation of emotive phraseologisms.

\section{Method of Investigation}

The research work is carried out by using the method of synchronic description of the analyzed material, based on the study and generalization of basic achievements of modern linguistics, theory of phraseology, and their chief conceptions.

The semantic-componential analysis method in the identification of phraseosemantic fields and the dictionary definition method in choosing the emotive phraseological units from bilingual and monolingual phraseological dictionaries have also been used in the article. 


\section{Scope of the Investigation}

In the phraseological system of any language phraseological units exist formulated in accordance with the system of emotional cognition and evaluation, peculiar to the bearer of this language. These expressions are considered as emotive phraseologisms or emosemed phraseological units. And they reflect most different attitudes of people, related to variety of views and assessment, linked with the cognition of the surrounding realities, and the processes taking place in the society to which they belong. In this respect investigation of emotive or emosemed units, existing in the phraseological system of any language can give its exclusive contribution to the determination of ethic-emotional character of the bearers of that language, and to the investigation of this or that language from linguoculturological aspect.

In the modern English language it is possible to find out the existence of a number of phraseological units, maintaining to the verbalization of "unexceptional emotions being psychical phenomenon", and the characterization of "emotional processes serving to cognize the information consciously or subconsciously". (Babushkina, 2012). We can give as an example the following phraseological units: be fed up to the back teeth, curdle someone's blood, get sick, gross one out, have had a gutful, make a face, make someone's toes curl, one's gorge rises, sick to one's stomach.

In the emotive phraseological units formulated by the influence of English culture and history, including the world culture and literary heritage as a whole, where the cognitive metaphors of the most different aspects are used, we can observe a number of interesting transferences, having the components of somatism, teonism or components with deonisms, including components with zoonyms.

\section{Study of Emotive Phraseological Units with Somatic Components}

Among emotive phraseological units with somatic components, expressions with kinesthetic basis are especially distinguished. It is worth mentioning that "emotionality in the cognition of a language is sensitive assessment of the object, a person's spiritual atmosphere, and expression of the feelings and excitements in a speech." (Кунин, 1996). As R. A. Ayupova noted that anything which we possess or anybody that we keep contact with provokes more or less emotions in us (Ayupova, 2008). This emotional background or emotional reactions in most cases possess kinesthetic expression. The word "kinesthetic" was formed by the unification of Greek words- "kinesis $\&$ aesthesis", which expresses "movement \& feeling, emotion", and "reactions starting from sensitive receptors of individually taken muscles of the parts of body" (Andrew, 2015). In other words, the main indications of emotive phraseological units possessing somatic component formulated on the kinesthetic background is conditioned by the mimic - gestural expression of the speaker's reaction in his/her attitude to the object. The phraseological unit look down (turn up) one's nose at somebody can be mentioned as an example (Hajiyeva, 2006). This expression, meaning "to view someone or something as lowly or unworthy", "consider oneself superior to others", reflects mimic reaction of a person against an object which causes indirect disgust:

Don't look down your nose at my car just because it's rusty and noisy. (Spears, 2005).

It is worth mentioning that the emotive phraseological unit with one's nose in the air is derived from the same semantic nuclear too (Kunin, 1996). Here also the moment of an arrogant person's holding his nose in the air haughtily gave way to the formation of the phraseological unit with negative connotation. This visually proves the truthfulness of the investigators' logical approach, who declared the idea that "in any word we can find the trace of a person" (Ayupova, 2009).

Charles de Gaulle arrived in the U.S. with his nose in the air; he considered Jackie empty and much too beau monde. (Time, 1994).

If we take into consideration that in the metaphoric coding in any developed world language, implication models deriving from anthropocentric cognition of the world establish leading position, in that case in most phraseological units, the fact that each man cognizes the world in a way he/she understands it, seems completely understandable. We should remind that, the term anthropocentric being the word combination of Greek word 'anthropos' ("human being") and Latin word 'centrum' ("centre") is used to name "the most harsh form of anthropomorphism". According to the anthropocentric approach the unit of measure of the knowledge on nature and society, including self cognition belongs to human being (Smirnova, 2001). In this respect it is impossible not to agree with the position of G. A. Bagautdinov, who stressed the fact in his investigation on the theme of "Human being in phraseology: anthropocentric and axiological aspects", saying that the units of this type of measure holds a leading position in a number of phraseosemantical fields. It is also interesting to note that, this scholar especially distinguishes phraseosemantic groups called "emotions and senses of human being" among the phraseosemantic groups with anthropocentric essence (Baqautdinova, 2007). Undoubtedly, if we speak from 
the point of this distribution we can convincingly say that the phraseological units in the English language such as grin from ear to ear, down in the mouth, laugh in someone's face and some others belong to the above mentioned phraseosemantic group. We must note that, while acting from the mechanism of subcoding, investigators, who analyzed the mechanism of anthropocentric conditioning of emotive phraseologisms, distinguish "anthroposensor subcodes" as a separate level and accept the belonging of phraseological units of kinesthetic essence just to the same level (Savchenko, 2014).

For example, the phraseological unit curl one's lip was formed on the kinesthetic basis. (Kunin, 1984). It's apparent that when we sneer or show our contempt corners of our upper lip are raised. (Siefring, 2004). Thus, here we cope with phraseological unit, derived from verbal representation of mimics, realized consciously or unconsciously in the concrete emotional state of a person. This expression visually affirms one interesting thought linked with emotive phraseologisms, declared by the compilers of the dictionary called "Oxford Dictionary of Idioms". Cowie A. P., Mackin R., \& McCaig I. R. note that, "certain idioms serve as expression of emotional state of the people about the negative or careless attitudes to the events which are being mentioned" (Cowie, Mackin, \& McCaig, 1994).

We must also mention the fact that, the specimens we have considered confirm R. A. Ayupova's thought, which says that "phraseological units possess the feature of assessment". The scholar adds to her thought linked with phraseologisms expressing emotions and feelings: "Emotive sememes also possess evaluating features" (Ayupova, 2009). In fact either the phraseological unit curl one's lip or look down (turn up) nose at somebody, or some other emotive phraseologisms, which we have considered in our investigation possess implicit or explicit feature of assessment.

As other kinesthetic-emotive phraseologisms with somatic components, the phraseological units such as set one's teeth and show / bare one's teeth can be given as examples (Kunin, 1984). Formed by the participation of somatic expression 'tooth (teeth)', these phraseological units are based upon quite distinctive kinesthetic reactions, and belong to the completely different phraseosemantical fields as well. Thus, the first expression - set one's teeth appeared as a result of person's clenching his/her teeth in order to endure sharp, piercing pain in human's disastrous state and belongs to the semantic field of phraseologisms, "endurance-patience". But the second expression-bare / show one's teeth bases on kinesthetic reaction - clenching one's teeth consciously or unconsciously while expressing his/her negative attitude in a certain situation. This emotive phraseologism logically belongs to the semantic field "careless (negative) attitude."

The phraseological unit bare / show one's teeth meaning "to act in an angry or threatening manner" indicates hostility and readiness to fight, as in His refusal to accept my offer made it clear I'd have to bare / show my teeth. (Ammer, 2013).

But here we must take into consideration that, anthropocentric approach appearing as the final limit of anthropomorphism, in some cases is associated with zoomorphic implication. Thus, Christine Ammer who etymologically estimated phraseological unit bare one's teeth being the synomym of the phraseological unit show one's teeth, in her lexicographic investigation called "The American Heritage Dictionary of Idioms", put forth the idea that negative attitude in both of these phraseologisms appeared on the transfering the snarl of a dog to human anger and stated that, while the phraseological unit show one's teeth was first recorded in 1615, the phraseological version bare one's teeth appeared later period of time" (Ammer, 2013).

We thought Bob was meek and mild, but he really showed his teeth when Jack insulted his girlfriend.

The enemy forces didn't expect the country they invaded to bare its teeth (Spears, 2005).

Another phraseological units which we are going to analyze share common features with phraseological units which we had investigated beforehand, since here too it is linked with the transition of zoomorphic approach to the anthropomorphic approach (Hajiyeva, 2004). The phraseological unit cast (make) sheep's eye at someone meaning "look at someone in a foolishly amorous way", (Siefring, 2004). "look at somebody with affection", was directly appeared in accordance with the kinesthetic state of a person, and belongs to the semantic field "love-admiration":

...when the young man casts sheep's eyes at the gel [= girl] every time she moves, and the gel is either singing about the house or sitting quiet as a mouse in a brown study — what do you think that means? (Richard Aldington, 'The Colonel's Daughter').

But alongside this, linking this state of a person with adequate zoomorphism, speaks of a different point, namely, of the fact in which the anthropocentric approach in person's cognition of himself / herself or the surrounding world can be crossed with zoomorphic approach. 
Dick Wilkinson in his investigation devoted to the analysis of the traditional English metaphors, drawing our attention to the semantic feature of the zoometaphor "sheep" which means a person deprived of enthusiasm, independence (that a sheep can't stay away from the flock), stressed the fact that plenty of phraseological units have been created with this word (the sheep could eat the grass through it, it is a fair flock that has no black sheep, black sheep of the family, there are two heads on all his sheep, a lazy sheep thinks its wool heavy etc.). And among them he mentioned the emotive phraseological unit cast (make) a sheep's eye at someone. (Wilkinson, 2009).

In the modern English language phraseologism cast (make) a sheep's eye at someone is distinguished by its high frequency of usage. Let's pay attention to the usage of this expression:

A fig for their nonsense and chatter!-suffice it, her Charms will excuse one for casting sheep's eyes at her! (Richard Harris Barham, "The Ingoldsby Legends").

There's a Grimm brothers fairytale about a simpleton who is instructed to go call someone out of a meeting by casting sheep's eyes at them. (Mary Scriver, "The Nasdijj Trilogy").

The phraseological unit have eyes (only) for someone or something included into the phraseosemantic field "love-admiration", serves as the verbal expression of positive emotions, meaning "be attracted to or desire someone or something (exclusively)", "feel amazement", "love somebody" etc. (Kunin, 1996). For example:

He has eyes only for the top award. (Ammer, 2013).

Are the stars out tonight?

I don't know if it's cloudy or bright

Cause I only have eyes for you, dear

The moon may be high

But I can't see a thing in the sky

Cause I only have eyes for you. (Al Dubin, Harry Warren, "I Only Have Eyes For You").

As to the emotive phraseological unit close (shut) one's eyes to something meaning "deliberately ignore something, refuse to notice; pretend that something is not happening", here too we cope with verbal expression of kinesthetic reaction. A person, either in an instant state of fear or anxiety, or when he/she meets an undesirable person or event, unwillingly shuts his/her eyes or evades his/her looks (Hajiyeva, 2006). For instance:

In the last few weeks, it has become clear to me that this peace and quiet may elude me if I shut my eyes to the all too obvious suffering of people around me. (Isidore Okpewho, "Tides").

The professor shut her eyes to students who read a book during her lecture. (Ammer, 2013).

The phraseological unit grin from ear to ear- "smile a very wide, beaming smile" is included into the phraseosemantic field "joy-happiness". In the "Cambridge Idioms Dictionary" it is noted that, this phraseologism expresses the meaning of a very happy view (Heacock, 2006).

She was grinning from ear to ear as she accepted the prize. We knew Timmy was happy because he was grinning from ear to ear. (Spears, 2005).

It becomes obvious from its meaning, here too, we deal with the fact in which semantic "platform" of the kinesthetic reaction of the phraseological unit is established.

The phraseological unit down in the mouth meaning "sad-faced; depressed and unsmiling" is also based on the kinesthetic reaction as in Try to cheer Jane up. She's down in the dumps for some reason.

About this in one of the sources we read: It's the way one looks when the corners of one's mouth are turned down in disheartenment or disappointment as a sign of misery (Heacock, 2006). Let's pay attention to the examples:

Since her dog died, Barbara has been down in the mouth. (Spears, 2005).

Bob has been down in the mouth since the car wreck. (Spears, 2005).

The phraseological unit make someone's mouth water does not acquire emotive essence in its first meaning which is "cause someone to salivate at the prospect of appetizing food", but in its second meaning acquires emotive essence, which is "cause someone to feel an intense desire to possess something". (Siefring, 2004). The first meaning of this phraseological unit appeared on the basis of the kinesthetic reaction, since seeing an appetizing meal creates an instinctive reaction in a person (cause saliva to flow in someone's mouth) as in: 
The sight of that chocolate cake made her mouth water. (Ammer, 2013).

That beautiful salad makes my mouth water. (Spears, 2005).

In the further stages this physiological reaction was not only linked with the goods of product, but also most probably, it was linked with other materials, objects on the basis of which, proper metaphorisms have appeared:

Those travel folders about Nepal make my mouth water. (Ammer, 2013).

This metaphoric term has been used figuratively since the mid-1600s, whether it refers to food or not (Ammer, 2013).

In the emotive phraseologism laugh in someone's face the attitude directly deriving from mockery, carelessness has found its reflection. But in the initial basis, the situation related to the body language has acted as in the role of semantic platform. (Hajiyeva, 2006). Phraseologism laugh in someone's face means "laugh in derision directly to someone's face"; "show displeasure or ridicule at something someone has said by laughing directly into one's face". For example:

"I asked Shiloh about being Aurora, and she laughed in my face," Jolie proudly recalled to Elle. Brad Pitt's fiancee added that her 7-year-old daughter "said she'd be a horned creature" instead. (www.usmagazine.com).

After I heard what she had to say, I just laughed in her face. (Spears, 2005).

As it can be seen, here the reaction of "to laugh" does not express a positive conception, but it expresses explicit negative or implicit negative attitude deriving from the attitude of mockery.

The all-rounded analysis of emotive phraseologisms with kinesthetic basis in the English language visually confirms A. Vejbitskaya's approach to the "lexicalized universal concepts in all the languages of the world". Thus, the scholar states that deriving from the format of manifestation of cultural norms, lexical universalities, finding their explicit way of expression in the form of cultural sceneries, assists to setting up the universal view of language without depending on the concrete language view of the world (Vejbitskaya, 2001). Thus, irrespective of language, religious view, racial belonging, any conscious individual possesses the collection of kinesthetic reactions of gestures and mimics bearing the feature of universal basic. Just, phraseological units basing on the same reactions have the same sounding with phraseological units in other languages, in most cases with languages which do not belong to the same language family, makes it possible to admit the existence of semantic universality of emotive phraseologisms with kinesthetic basis.

\section{Conclusion}

Summing up the above-mentioned issues we would like to add that, as it is known from the examples, in the phraseological units basing on the kinesthetic reactions, directly the names of the parts of body, taking part in the "body language", are used. Concretely, we can affirm the participation of somatisms, such as nose, mouth, eye, lip, face, etc. in the phraseological units which we have considered as examples. The expressions with which these somatisms have been used, in conformity with the kinesthetic reactions, that they express, have been subjected to receiving abstract meanings, and have acquired proper phraseological notion.

Variety of types of inner forms of phraseological units based on metaphor can refer to three corresponding elements of feelings determined in psychology; 1) physiological changes of inner organs and physiological sensation of the person in a certain emotional state; 2) behavioral reaction of the person including mimics, gestures, movements of body and active action of the person; 3 ) inner state of anxiety.

\section{References}

Andrew, M. C. (2015). A Dictionary of Psychology. Oxford: Oxford University Press.

Ammer, C. (2013). The American Heritage Dictionary of Idioms. Boston: Houghton Mifflin Harcourt, Second Edition Paperback.

Ayupova, R. A. (2009). Problems of Lexicographical Description of Phraseological Units (on the materials of English, Russian and Tatar languages). Abstract of dissertation ..... Doctor of philological Sciences, Kazan.

Ayupova, R. A. (2008). Phraseological Emotivity in the Lexicographical Description and in the Context (on the material of English, Russian and Tatar languages). II Scientific News of Russian State Pedagogical University named after A. I. Gertsen. Social and Humanitarian Sciences.

Babushkina, O. N., \& Kiselev, D. A. (2012). The Role of Cognitive Metaphors in Indirect-Derivative Nomination of Emotions. Electronic Scientific Journal "Language and Philological Studies", 4(2). Moscow. 
Baqautdinova, G. A. (2007). Human Being in Phraseology: Anthropocentric and Axiological Aspects. Abstract of dissertation.... Doctor of philological Sciences, Kazan.

Cowie, A. P., Mackin, R., \& McCaig, I. R. (2007). Oxford Dictionary of English Idioms. Oxford: Oxford University Press.

Hajiyeva, A. H. (2006). The Principles of Somatic Phraseologisms in the English and Azerbaijani languages. Baku: Nurlan.

Hajiyeva, A. H. (2006). English-Azerbaijani Phraseological Dictionary. Baku: Nurlan.

Hajiyeva, A. K. (2004). Dictionary of English and Azerbaijani Zoometaphorisms. Baku: Nurlan.

Heacock, P. (2006). Cambridge Idioms Dictionary (2nd ed.). Cambridge: Cambridge University Press.

Kunin, A. V. (1984). English-Russian Phraseological Dictionary. Moscow.

Kunin, A. V. (1996). A Course in Modern English Phraseology. Moscow.

Savchenko, L. V. (2014). Model of Anthropic Code of Culture in the Phraseological Map of the World. Universum: Philology and Art Study, 7(9).

Siefring, J. (2004). Oxford Dictionary of Idioms (2nd ed.). Oxford: Oxford University Press.

Smirnova, N. M. (2001). Anthropocentrism / New Philosophical Encyclopedia: Thought, under the editorship of V.S. Stepin.

Spears, R. A. (2005). McGraw-Hill's Dictionary of American Idioms and Phrasal Verbs. New York: McGraw-Hill Companies, Inc.

Vejbitskaya, A. (2001). Comparison of Cultures through Means of Lexics and Paradigmatic / translation from the English language. A.D. Shmeleva, Languages of Slavic Culture. Moscow.

Wilkinson, D. C. (2002). Thesaurus of Traditional English Metaphors (2nd ed.). London: Routledge.

\section{Copyrights}

Copyright for this article is retained by the author(s), with first publication rights granted to the journal.

This is an open-access article distributed under the terms and conditions of the Creative Commons Attribution license (http://creativecommons.org/licenses/by/3.0/). 